\title{
LAJU TANGKAP DAN KOMPOSISI JENIS IKAN DEMERSAL DAN UDANG YANG TERTANGKAP TRAWL PADA MUSIM TIMUR DI PERAIRAN UTARA JAWA TENGAH
}

\author{
Bambang Sumiono", Sudjianto"), Yunus Soselisa"), dan TS Murtoyo"*)
}

\begin{abstract}
ABSTRAK
Penelitian sumber daya ikan demersal dan udang dengan trawl terutama pada kedalaman lebih dari $30 \mathrm{~m}$ dilakukan di perairan utara Jawa Tengah pada musim timur (Juni 2000) berdasarkan metode sapu (swept area method) dengan menggunakan kapal penelitian Mutiara IV (100 GT). Analisis terhadap 29 stasiun pengamatan menunjukkan rata-rata laju tangkap ikan demersal sebesar $43,3 \mathrm{~kg} / \mathrm{jam}$ dengan kepadatan stok $0,8 \mathrm{ton} / \mathrm{km}^{2}$, sedangkan laju tangkap udang $0,9 \mathrm{~kg} / \mathrm{jam}$ dengan kepadatan stok 0,02 ton $/ \mathrm{km}^{2}$. Laju tangkap yang mengalami peningkatan secara nyata terjadi pada periode tahun 1980-1990, pada saat ini telah mengalami kecenderungan menurun. Diduga perubahan ini timbul sebagai akibat dari tingginya laju penangkapan di perairan tersebut. Konsentrasi daerah penyebaran ikan demersal terdapat pada kedalaman antara 31-40 m. Jenis ikan demersal didominasi oleh peperek (Leiognathidae) dan kurisi (Nemipteridae), sedangkan udang didominasi oleh jenis krosok (Tracypenaeus asper) dan dogol (Metapenaeus ensis).
\end{abstract}

ABSTRACT: Cath rates and catch composition of demersal fish and shrimps caught by trawl during the east monsoon in the waters north of Central Java. By: Bambang Sumiono, Sudjianto, Yunus Soeselisa, and T.S. Murtoyo

\begin{abstract}
Research on demersal and shrimp resources using trawl was carried out during the East monsoon (June, 2000) at the depth > $30 \mathrm{~m}$ in the waters north of Central Java, using the research vessel "Mutiara-IV" (100 GT). Stock density was calculated by swept-area method. Based on the catch rates obtained from 29 stations the average catch rate of demersal fish in this area was $43.3 \mathrm{~kg} / \mathrm{hr}$, and the estimated stock density was 0.8 ton $/ \mathrm{kmi}^{2}$. Meanwiile, the catch rate of shrimp was $0.9 \mathrm{~kg} / \mathrm{hr}$ with a stock density of 0.02 ton $/ \mathrm{km}^{2}$. Catch rates of demersal fish increased significantly in the period 1980 1990, however, more recently the rates tend to decrease. This is probably due to high exploitation of the resources in these areas. The concentration of fish was mainly distributed between the depths of $31-40 \mathrm{~m}$. The dominant families of the demersal fish were Leiognathidae and Nemipteridae, while the dominant species of shrimps were Trachypenaeus asper and Metapenaeus ensis.
\end{abstract}

KEYWORDS: $\quad$ catch rate, catch composition, demersal fish, east monsoon

\section{PENDAHULUAN}

Laut Jawa sebagai bagian dari Paparan Sunda memiliki kedalaman perairan yang relatif dangkal, merupakan daerah penangkapan ikan demersal dan udang yang potensial di kawasan barat Indonesia. Perairan di sebelah utara Jawa Tengah merupakan daerah penangkapan ikan demersal dan udang yang diusahakan sejak awal tahun 1970-an. Luas daerah penangkapan ikan di perairan pantai utara Jawa Tengah sekitar 16.300 $\mathrm{km}^{2}$ dan perairan lepas pantai sebesar $46.600 \mathrm{~km}^{2}$ (Losse \& Dwiponggo, 1977).

Indikasi pulinnya stok sumber daya ikan demersal di perairan utara Jawa Tengah pernah dilaporkan oleh Badrudin (1987), namun pulihnya stok udang masih dipertanyakan. Di lain pihak, pada saat ini sebagian besar alat tangkap udang yang digunakan bersifat aktif, sehingga produksi udang yang pada awal berlakunya Keppres No.

\footnotetext{
*) Peneliti pada Balai Riset Perikanan Laut, Jakarta

*) Peneliti pada Balai Pengkajian Teknologi Pertanian, Ungaran
}

$39 / 1980$ tentang penghapusan trawl turun drastis, pada saat ini menunjukkan peningkatan kembali.

Informasi tentang indeks kepadatan stok (laju tangkap) sumber daya perikanan sesuai dengan tempat dan waktu, merupakan salah satu dasar bagi keberhasilan usaha penangkapan. Penelitian tentang status pengusahaan sumber daya perikanan demersal di Laut Jawa telah dimulai sejak tahun 1975 dengan menggunakan sarana kapal penelitian Mutiara IV. Hasil survei dengan trawl yang meliputi variasi laju tangkap (catch rate) dan komposisi hasil tangkapan ikan demersal pada periode sebelum penghapusan trawl telah banyak dibahas (Beck \& Sudradjat, 1978).

Kegiatan penelitian dan pemantauan khususnya di perairan utara Jawa Tengah masih berlangsung sampai saat ini, hasilnya masih perlu dikaji sesuai dengan kebutuhan dasar bagi penentu kebijakan dalam mengelola sumber daya ikan di daerah ini. 


\section{BAHAN DAN METODE}

Pengambilan sampel sumber daya ikan demersal dan udang di perairan utara Jawa Tengah dilakukan dengan menggunakan trawl pada bulan Juni 2000, mulai dari perairan antara Semarang-Pekalongan (di sebelah barat) dan antara Rembang-Lasem (di sebelah timur) pada kisaran kedalaman 30-60 m (Gambar 1). Wahana yang digunakan adalah kapal penelitian "Mutiara IV" (100 GT). Alat trawl yang digunakan dilengkapi dengan tali ris atas yang panjangnya $28,5 \mathrm{~m}$, panjang tali ris bawah $32,5 \mathrm{~m}$, dan ukuran mata jaring bagian kantong $30 \mathrm{~mm}$ (Gambar.2).

Kep. Karimun Jawa

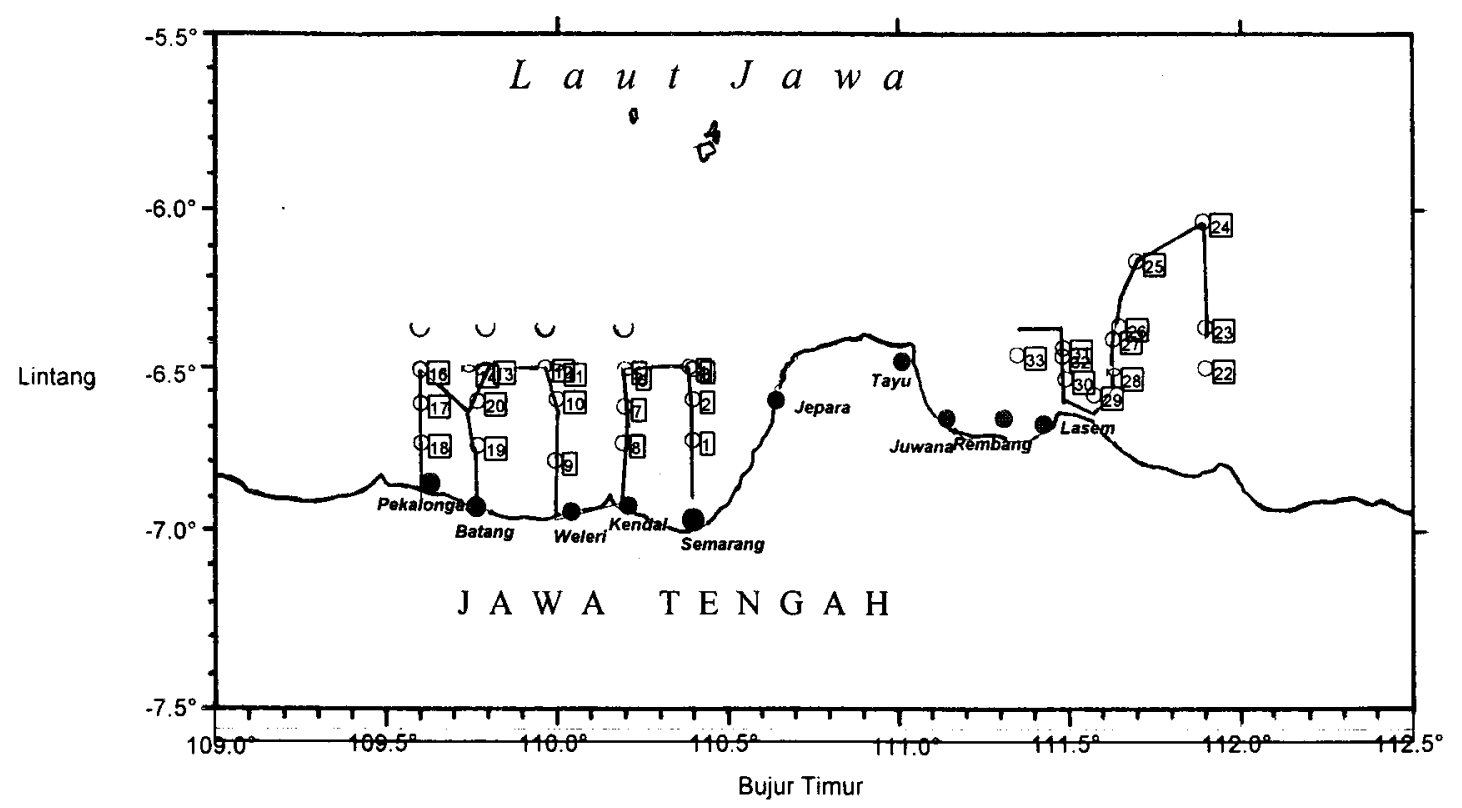

Gambar 1. Penyebaran stasiun penangkapan dengan trawl di perairan utara Jawa Tengah, Juni 2000.

Figure 1. Distribution of fishing station by trawl in the north of Central Java, June 2000.

Penarikan jaring pada setiap stasiun penelitian berlangsung selama satu jam, dengan kecepatan kapal rata-rata 3 knot dan dilakukan pada siang hari antara pukul 05.00-18.00. Identifikasi jenis ikan hasil tangkapan dilakukan dengan mengacu pada Fischer \& Whitehead (1974).

Perhitungan laju tangkap dan kepadatan stok ikan menggunakan metode sapuan (swept area method) menurut luas area yang diliput, kecepatan kapal waktu menarik jaring, lebar bukaan mulut jaring, dan hasil tangkapan (Sparre \& Venema, 1992) sebagai berikut:

$$
\begin{aligned}
& a \cdot n=t \times \vee \times h \times e \times 1,852 \times 0,001 \\
& D=(1 / a . n) \times(c / f)
\end{aligned}
$$

di mana:

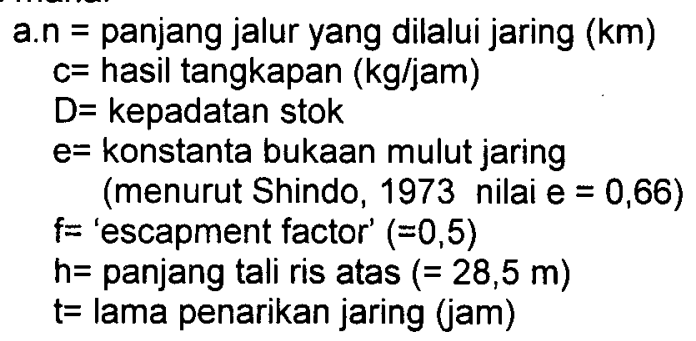

$v=$ rata-rata kecepatan kapal waktu menarik jaring (knot)

$1,852=$ konversi mil ke $\mathrm{km}$

$0,001=$ konversi dari meter $\mathrm{ke} \mathrm{km}$

\section{HASIL DAN BAHASAN}

\section{Laju Tangkap}

Dari 29 stasiun penangkapan yang berhasil selama penelitian di perairan utara Jawa terutama pada kedalaman lebih dari $30 \mathrm{~m}$, diperoleh ratarata laju tangkap ikan demersal sebesar 43,3 $\mathrm{kg} / \mathrm{jam}$ atau $87,8 \%$ dari total laju tangkap, sedangkan laju tangkap udang $0,9 \mathrm{~kg} / \mathrm{jam}$ atau $1,83 \%$ dari total laju tangkap (Tabel 1).

Ditinjau menurut sub areanya, maka laju tangkap ikan demersal dan udang di perairan antara Semarang-Pekalongan lebih tinggi dari pada perairan antara Pati-Rembang.

Sedikitnya hasil tangkapan udang pada penelitian ini, diduga selain disebabkan oleh rancang bangun trawl ikan yang kurang sesuai 


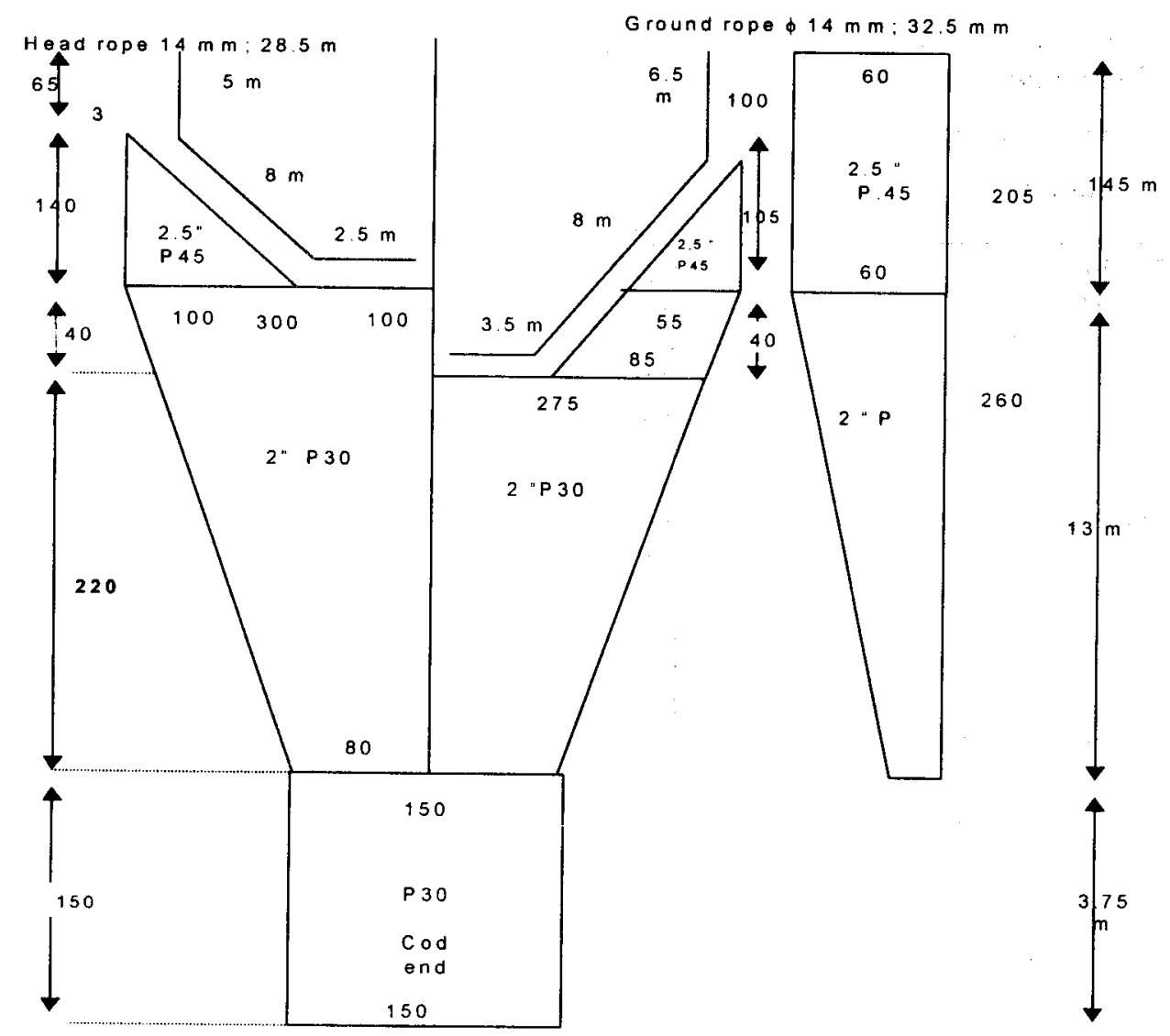

Gambar 2. Rancang bangun trawl yang digunakan oleh KM Mutiara IV.

Figure 2. Design of trawl net used by RV Mutiara IV.

untuk menangkap udang, juga kemungkinan adanya indikasi bahwa populasi udang di daerah sampling yang memang sedikit atau disebabkan oleh faktor lainnya. Seperti diketahui daerah yang diliput pada penelitian ini terutama pada kedalaman antara $30-60 \mathrm{~m}$, hanya 3 stasiun penangkapan pada kedalaman 20-30 m di perairan sebelah barat. Dasar perairan mulai dari perairan Jepara ke arah timur, lebih banyak berupa pasir atau pasir campur lumpur. Menurut Penn (1984) habitat yang sesuai untuk kehidupan udang penaeid terutama pada kedalaman antara 10-30 $m$ dengan dasar perairan terutama berlumpur serta masih dipengaruhi oleh massa air tawar (freshwater discharge).

Keberhasilan usaha penangkapan udang selain dipengaruhi oleh kondisi lingkungan perairan setempat, juga bergantung kepada daya tangkap (fishing power), sifat mudah kena (vulnerability), dan banyak sedikitnya kelompok udang serta kemampuan dan strategi penangkapan yang berhubungan dengan ketrampilan juru mudi. Menurut (Caddy vide Penn, 1984) besar kecilnya kelompok udang secara langsung berkaitan erat dengan sifat (behaviour) jenis udang. Udang jerbung dan dogol lebih menyenangi kelompok yang berjumlah besar terutama pada pagi hari, sedangkan udang windu bersifat soliter dan lebih banyak tertangkap pada malam hari.

Rata-rata laju tangkap ikan demersal yang diperoleh pada penelitian ini, bila dibandingkan dengan penelitian sebelumnya (tahun 1975-1979) pada musim yang sama ternyata memperlihatkan penurunan yang cukup tajam. Badrudin (1985) menyatakan hasil penelitian dengan KM Mutiara IV pada musim timur di utara Jawa Tengah berturutturut memperoleh laju tangkap ikan demersal sebesar $150 \mathrm{~kg} / \mathrm{jam}$ (1975), $131 \mathrm{~kg} / \mathrm{jam}$ (1977). dan $178 \mathrm{~kg} / \mathrm{jam}$ (1984). Dikemukakan pula bahwa ikan demersal di pantai utara Jawa Tengah tidak memperlihatkan kecenderungan untuk menggerombol secara musiman. Secara geografis, perairan pantai utara Jawa merupakan wilayah yang terbuka, baik pada musim timur maupun pada musim barat.

Indikasi penurunan laju tangkap ini juga ditunjukkan dari hasil penelitian di Pati-Rembang, di mana laju tangkap ikan demersal sebesar 41,8 $\mathrm{kg} / \mathrm{jam}$ menurun sekitar $32 \%$ dari hasil penelitian pada bulan Juni 1989 yaitu $61,7 \mathrm{~kg} / \mathrm{jam}$ (Suhendrata \& Badrudin, 1990). 
Tabel 1. Laju tangkap ( $\mathrm{kg} / \mathrm{jam})$ ikan demersal dan udang menurut famili dan sub area

Table 1. Catch rate $(\mathrm{kg} / \mathrm{hr})$ of demersal fish and shrimp by families and sub areas

\begin{tabular}{lcccc}
\hline \multicolumn{1}{c}{ Famili (Family) } & $\begin{array}{c}\text { Semarang- } \\
\text { Pekalongan } \\
(\mathbf{n = 1 8})\end{array}$ & $\begin{array}{c}\text { Rembang-Lasem } \\
\mathbf{( n = 1 1 )}\end{array}$ & $\begin{array}{c}\text { Jumlah } \\
\text { (Total) }\end{array}$ & $\begin{array}{c}\text { Rata-Rata } \\
\text { (Average) }\end{array}$ \\
\hline Ariidae (manyung) & 0,5 & 0,0 & 0,5 & 0,3 \\
Balistidae (kambingan) & 0,1 & 0,2 & 0,3 & 0,2 \\
Formionidae (bawal hitam) & 0,0 & 0,0 & 0,0 & 0,0 \\
Gerreidae (kapasan) & 0,9 & 0,5 & 1,4 & 0,7 \\
Psetodidae (ikan sebelah) & 1,7 & 2,1 & 3,8 & 1,9 \\
Lactaridae (ikan putihan) & 0,0 & 0,3 & 0,3 & 0,2 \\
Leiognathidae (peperek) & 22,0 & 23,0 & 45,0 & 22,5 \\
Lutjanidae (kakap) & 1,6 & 0,7 & 2,3 & 1,2 \\
Mullidae (kuniran,) & 1,0 & 0,9 & 1,9 & 1,0 \\
Muraenosocidae (remang) & 0,5 & 0,0 & 0,5 & 0,3 \\
Nemipteridae (kurisi) & 4,7 & 5,3 & 10,0 & 5,0 \\
Pentapodidae (kepala batu) & 0,0 & 0,0 & 0,0 & 0,0 \\
Polynemidae (kuro) & 0,0 & 0,0 & 0,0 & 0,0 \\
Pomadasyidae (gerot-gerot) & 0,2 & 0,0 & 0,2 & 0,1 \\
Priachanthidae (swanggi) & 0,7 & 0,3 & 1,0 & 0,5 \\
Sciaenidae (gulamah, tigawaja) & 0,4 & 0,1 & 0,5 & 0,3 \\
Serranidae (kerapu) & 0,9 & 0,7 & 1,6 & 0,8 \\
Stromateidae (bawal putih) & 0,2 & 0,2 & 0,4 & 0,2 \\
Synodontidae (beloso) & 3,3 & 1,2 & 4,5 & 2,3 \\
Theraphonidae (kerong-2) & 0,0 & 0,0 & 0,0 & 0,0 \\
Trichiuridae (layur) & 1,1 & 4,7 & 5,8 & 2,8 \\
Others (ikan lainnya) & 0,6 & 0,3 & 0,9 & 0,5 \\
Trash Fish (ikan rucah) & 4,2 & 1,5 & 5,7 & 2,8 \\
\hline TOTAL DEMERSAL & 44,7 & 41,8 & 86,5 & 43,3 \\
\hline \% Demersal & 85,00 & 90,00 & 88,0 & 87,80 \\
\hline Shrimps(Udang) & 1,5 & 0,2 & 1,7 & 0,9 \\
\hline \% Udang & 2,85 & 0,44 & 1,70 & 1,83 \\
\hline TOTAL CATCHRATE & 52,6 & 46,0 & 98,6 & 49,3 \\
\hline
\end{tabular}

Namun untuk beberapa jenis ikan yang berumur pendek dan berukuran relatif kecil menunjukkan laju tangkap lebih tinggi, antara lain terdapat pada famili Leiognathidae (peperek) sebesar 22,5 kg/jam dan Nemipteridae (kurisi) 5,0 $\mathrm{kg} / \mathrm{jam}$. Menurut Shindo (1973) jenis-jenis ikan yang berukuran kecil di perairan tropis mempunyai kemampuan pulih yang tinggi jika dibandingkan dengan ikan-ikan yang berukuran besar.

Pemantauan yang dilakukan pada periode 1984-1986 oleh (Nugroho \& Badrudin, 1987) menunjukkan bahwa laju tangkap dan sediaan ikan demersal pada tahun 1986 mencapai kelipatan 2-3 kali lebih tinggi dibandingkan pada tahun 19751979. Peningkatan ini juga dilaporkan oleh Rijal \& Sumiono, 1989 yang mengatakan bahwa laju tangkap ikan demersal di perairan utara Semarang-Pekalongan naik $41 \%$ dibandingkan dengan tahun 1978 di lokasi yang sama.

Dengan demikian, secara umum dapat dikatakan bahwa laju tangkap (sediaan) ikan demersal yang mengalami peningkatan secara signifikan pada periode tahun 1980-1990, pada saat ini telah mengalami kecenderungan menurun. Penurunan ini diduga ada kaitannya dengan semakin berkembangnya berbagai bentuk alat tangkap yang kurang selektif. Sejak tahun 1990-an di kawasan pantai utara Jawa bertambah banyak jumlah (unit) alat tangkap untuk ikan demersal dan udang, antara lain trammel net, jaring klitik (gill net monofilamen), dogol, cantrang, dan arad. Dua jenis yang disebut terakhir penggunaannya mirip dengan trawl, yaitu menggunakan sewakan dan ditarik secara aktif dari perahu yang bergerak.

\section{Penyebaran Menurut Kedalaman Dasar Perairan}

Berdasarkan strata kedalamannya, diperoleh penyebaran rata-rata laju tangkap ikan demersal yang paling tinggi terdapat pada kedalaman antara $31-40 \mathrm{~m}$ yaitu $78,7 \mathrm{~kg} / \mathrm{jam}$. Penyebaran paling rendah terdapat pada kedalaman antara 51-60 m yaitu $26,7 \mathrm{~kg} / \mathrm{jam}$ (Tabel 2 ). 
Tabel 2. Laju tangkap ikan demersal $(\mathrm{kg} / \mathrm{jam})$ menurut strata kedalaman perairan

Table 2. Catch rate of demersal fish ( $\mathrm{kg} / \mathrm{hour}$ ) by depth ranges

\begin{tabular}{cccccccc}
\hline $\begin{array}{c}\text { Kedalaman } \\
\text { (Depth) } \\
(\mathbf{m})\end{array}$ & $\begin{array}{c}\text { JmI Sta. } \\
\text { (Number } \\
\text { of Station) }\end{array}$ & Total & $\begin{array}{c}\text { Rata-Rata } \\
\text { (Average) }\end{array}$ & $\begin{array}{c}\text { Jml Sta } \\
\text { (Number of } \\
\text { Station) }\end{array}$ & Total & $\begin{array}{c}\text { Rata-rata } \\
\text { (Average) }\end{array}$ & $\begin{array}{c}\text { Rata-rata } \\
\text { (Average) }\end{array}$ \\
\hline $21-30$ & 3 & 124,9 & 41,6 & - & - & - & 41,6 \\
$31-40$ & 4 & 292,9 & 73,2 & 3 & 84,2 & 84,2 & 78,7 \\
$41-50$ & 11 & 336,1 & 30,6 & 5 & 24,6 & 24,6 & 27,6 \\
$51-60$ & - & - & - & 3 & 26,7 & 26,7 & 26,7 \\
\hline
\end{tabular}

Fenomena yang menarik yaitu terjadinya perubahan konsentrasi daerah penyebaran ikan jika dibandingkan dengan keadaan pada saat trawl masih boleh beroperasi (sebelum tahun 1980). Dari Tabel 2 tersebut tampaknya penyebaran ikan demersal di utara Jawa Tengah pada saat penelitian terkonsentrasi pada kedalaman antara 31-40 m. Pada tahun 1975-1979 penyebaran laju tangkap cenderung lebih tinggi pada kedalaman kurang dari $30 \mathrm{~m}$ (Nugroho \& Badrudin, 1987). Perubahan ini kemungkinan dipengaruhi oleh perkembangan aktivitas penangkapan ikan demersal pada saat ini yang lebih intensif dilakukan dengan berbagai bentuk alat tangkap yang lebih banyak dioperasikan pada kedalaman kurang dari $30 \mathrm{~m}$.

\section{Kepadatan Stok}

Berdasarkan perhitungan dengan metode swept area dan laju tangkap ikan demersal sebesar $43,3 \mathrm{~kg} / \mathrm{jam}$, maka kepadatan stok pada bulan Juni (musim timur) di utara Jawa Tengah pada kedalaman lebih dari $20 \mathrm{~m}$ sebesar 0,8 ton $/ \mathrm{km}^{2}$. Dibandingkan dengan keadaan sebelum penghapusan trawl pada tahun 1980 yang kepadatannya 2,4 ton/tahun (Losse \& Dwiponggo,
1977), maka laju tangkap ikan demersal di utara Jawa Tengah pada saat ini menurun drastis. Bila laju tangkap udang $0,9 \mathrm{~kg} / \mathrm{jam}$, maka kepadatan udang pada kedalaman lebih dari $30 \mathrm{~m}$ sekitar 0,02 ton $/ \mathrm{km}^{2}$.

Ditinjau dari sub areanya, dengan laju tangkap $44,7 \mathrm{~kg} / \mathrm{jam}$, maka kepadatan stok di perairan sebelah "barat" sebesar 0,83 ton $/ \mathrm{km}^{2}$. Sedangkan laju tangkap di perairan sebelah "timur" 41,6 $\mathrm{kg} / \mathrm{jam}$, maka kepadatan stoknya relatif sama yaitu 0,80 ton $/ \mathrm{km}^{2}$. Nilai-nilai tersebut lebih rendah sekitar 3-4 kali dari hasil yang diperoleh pada tahun 1979 dan 1989 (Suhendrata \& Badrudin, 1990). Hasil temuan ini membuktikan adanya penurunan stok ikan demersal di perairan Laut Jawa.

Di samping itu tampak adanya perubahan konsentrasi ikan demersal menurut kedalaman. Berdasarkan Tabel 3 kepadatan stok tertinggi terdapat pada kedalaman antara $31-40 \mathrm{~m}$ yaitu sebesar $1,5 \mathrm{ton} / \mathrm{km}^{2}$ dan terendah pada $51-60 \mathrm{~m}$, sebesar 0,5 ton $/ \mathrm{km}^{2}$. Pada periode 1975-1979 kepadatan stok ikan demersal di utara Jawa Tengah terkonsentrasi pada kedalaman antara 10 $30 \mathrm{~m}$ (Nugroho \& Badrudin, 1987).

Tabel 3. Laju tangkap dan kepadatan stok ikan demersal menurut strata kedalaman

Tabe/ 3. Catch rates and stock densities of demersal fish by depth range

\begin{tabular}{|c|c|c|c|c|c|c|}
\hline \multirow[b]{2}{*}{$\begin{array}{c}\text { Strata } \\
\text { Kedalaman } \\
\text { (Depth range }) \\
(\mathrm{m})\end{array}$} & \multicolumn{2}{|c|}{ Semarang-Pekalongan } & \multicolumn{2}{|c|}{ Rembang-Lasem } & \multicolumn{2}{|c|}{ Rata-rata (Average) } \\
\hline & $\begin{array}{c}\text { Rata-rata laju } \\
\text { tkp. } \\
\text { (Average } \\
\text { catch rate) } \\
\text { (kg/jam) } \\
\end{array}$ & $\begin{array}{l}\text { Kepadatan } \\
\text { stok } \\
\text { (Stock } \\
\text { density) } \\
\text { (ton } / \mathrm{km}^{2} \text { ) } \\
\end{array}$ & $\begin{array}{c}\text { Rata-rata laju } \\
\text { tkp. } \\
\text { (Average } \\
\text { catch rate) } \\
\text { (kg/jam) } \\
\end{array}$ & $\begin{array}{l}\text { Kepadatan } \\
\text { stok } \\
\text { (Stock } \\
\text { density) } \\
\text { (ton } / \mathrm{km}^{2} \text { ) } \\
\end{array}$ & $\begin{array}{c}\text { Laju tkp. } \\
\text { (Catch rate) } \\
\text { (kg/jam) }\end{array}$ & $\begin{array}{c}\text { Kepadatan } \\
\text { Stok } \\
\text { (Stock density) } \\
\text { (ton } / \mathrm{km}^{2} \text { ) }\end{array}$ \\
\hline $21-30$ & 41,6 & 0,8 & - & - & 41,6 & 0,8 \\
\hline $31-40$ & 73,2 & 1.4 & 84,2 & 1,6 & 78,7 & 1,5 \\
\hline $41-50$ & 30,6 & 0,6 & 24,6 & 0,5 & 27,6 & 0,6 \\
\hline $51-60$ & - & - & 26,7 & 0,5 & 26,7 & 0,5 \\
\hline
\end{tabular}




\section{Komposisi Hasil Tangkapan}

Persentase laju tangkap terhadap total ikan demersal menunjukkan komposisi hasil tangkapan yang sama antara sub area sebelah barat dan timur yaitu didominasi oleh famili Leiognathidae (peperek) dan Nemipteridae (kurisi). Khusus untuk famili Lutjanidae (kakap) dan Synodontidae (beloso) lebih banyak tertangkap di perairan sub area barat, sedangkan famili Heterostomata (ikan sebelah) dan Trichiuridae (layur) lebih banyak tertangkap di sub area timur (Tabel 4). Dominasi kelompok ikan ini kurang lebih sama dengan hasil tangkapan trawl pada tahun 1975-1979 sesuai dengan hasil penelitian (Losse \& Dwiponggo, 1997; Nugroho \& Badrudin (1987); Badrudin, 1985). Namun terdapat penurunan persentase kelompok Ariidae (manyung), Priacanthidae (swangi), dan Lutjanidae (kakap). Terjadinya perubahan komposisi hasil tangkapan ini kemungkinan disebabkan oleh pengaruh musim dan atau banyaknya jenis alat tangkap yang beroperasi pada saat ini.

Komposisi hasil tangkapan udang pada kedalaman lebih dari $30 \mathrm{~m}$ didominasi oleh jenis krosok (Trachypenaeus asper) sedangkan udang dogol (Metapenaeus ensis) dan jerbung (Penaeus merguiensis) terutama pada kedalaman kurang dari $30 \mathrm{~m}$. Pada penelitian ini diperoleh jenis udang windu Penaeus semisulcatus di utara Pekalongan dan udang windu jenis Penaeus monodon di utara Lasem, dengan laju tangkap yang sangat rendah yaitu kurang dari 0,5 kg/jam atau 2-3 ekor/ jam.

Tabel 4. Persentase terhadap laju tangkap total ikan demersal menurut famili dan sub area

Table 4. The percentage of total catch rates of demersal fish by families and sub areas

\begin{tabular}{|c|c|c|}
\hline Famili (Family) & Semarang-Pekalongan & Rembang-Lasem \\
\hline Ariidae & 1,15 & 0,02 \\
\hline Balistidae & 0,18 & 0,58 \\
\hline Formionidae & 0,00 & 0,02 \\
\hline Gerreidae & 2,02 & 1,15 \\
\hline Psetodidae & 3,69 & 5,09 \\
\hline Lactaridae & 0,00 & 0,66 \\
\hline Leiognathidae & 49,13 & 54,92 \\
\hline Lutjanidae & 3,63 & 1,58 \\
\hline Mullidae & 2,13 & 2,17 \\
\hline Muraenosocidae & 1,08 & 0,00 \\
\hline Nemipteridae & 10,39 & 12,72 \\
\hline Pentapodidae & 0,01 & 0,00 \\
\hline Polynemidae & 0,03 & 0,01 \\
\hline Pomadasyidae & 0,50 & 0,07 \\
\hline Priachanthidae & 1,55 & 0,68 \\
\hline Sciaenidae & 0,81 & 0,12 \\
\hline Serranidae & 2,09 & 1,63 \\
\hline Stromateidae & 0,37 & 0,37 \\
\hline Synodontidae & 7,28 & 2,79 \\
\hline Theraphonidae & 0,01 & 0,02 \\
\hline Trichiuridae & 2,38 & 11,20 \\
\hline
\end{tabular}

\section{KESIMPULAN}

1. Laju tangkap ikan demersal dengan trawl di utara Jawa Tengah pada musim timur sebesar $43,3 \mathrm{~kg} / \mathrm{jam}$ dan laju tangkap udang $0,9 \mathrm{~kg} / \mathrm{jam}$ atau $1,83 \%$ nya. Laju tangkap ikan demersal yang mengalami peningkatan secara nyata pada periode tahun 1970-1980, pada saat ini telah mengalami penurunan drastis yaitu dari antara $131-178 \mathrm{~kg} / \mathrm{jam}$ menjadi 43,3 kg/jam.

2. Konsentrasi terpadat daerah penyebaran ikan demersal terdapat pada kedalaman antara 31$40 \mathrm{~m}$ dan paling sedikit terdapat pada kedalaman antara 51-60 m.
3. Kepadatan stok ikan demersal pada musim timur di utara Jawa Tengah sebesar 0,8 ton $/ \mathrm{km}^{2}$. Kepadatan tertinggi $\left(1,5\right.$ ton $\left./ \mathrm{km}^{2}\right)$ terdapat pada kedalaman antara $31-40 \mathrm{~m}$ dan terendah $\left(0,5\right.$ ton $\left./ \mathrm{km}^{2}\right)$ pada kedalaman 5-60 $\mathrm{m}$. Kepadatan stok udang pada kedalaman lebih dari $30 \mathrm{~m}$ adalah 0,02 ton $/ \mathrm{km}^{2}$.

4. Komposisi hasil tangkapan trawl didominasi oleh famili Leiognathidae (peperek) dan Nemipteridae (kurisi). Famili Lutjanidae (kakap) dan Synodontidae (beloso) lebih banyak tertangkap di perairan antara Semarang-Pekalongan, sedangkan famili Heterostomata (ikan sebelah) dan Trichiuridae 
(layur) lebih banyak tertangkap di perairan utara Rembang-Lasem. Hasil tangkapan udang didominasi oleh jenis krosok (Trachypenaeus asper).

\section{DAFTAR PUSTAKA}

Badrudin, M. 1985. Perubahan musiman tingkah laku gerombolan ikan demersal di perairan sub area Laut Jawa. Makalah disampaikan pada Konggres Biologi Nasional VII. Universitas Sriwidjaja Palembang; 9 hal. (tidak dipublikasikan).

Badrudin, M. 1987. The demersal fish stock in the north coast of Central Java with special reference to the stock parameters of the splendid pony-fish, Leiognathus splendens. MSc Disertation. SAB-UCNW, Bangor, UK.

Beck, U \& A. Sudradjat. 1978. Variations an size and composition of demersal trawl catches from the Northcoast of Java with estimated growth parameters for three important food-fish species. Contrib. of the Dem. Fish. Project No.4/1978. 3, 1977. Mar. Fish. Res. Inst. Jakarta. Hal: 1--80.

Fischer,W \& P.J.P.Whitehead. 1974. Identification sheets for fishery purpose. Eastern Indian Ocean (Fishery Area 71), Vol. I-IV, FAO Rome

Losse,G.F. \& A. Dwiponggo. 1977. Report on the Java Sea SE monsoon trawl survey. June-
December 1976. Spec. Rep. Contrib. of the Dem. Fish. Project No.3. Mar. Fish. Res. Inst. Jakarta.

Nugroho,D \& M. Badrudin. 1987. Analisis laju tangkap sumber daya perikanan demersal pada periode 1975-1979 dan 1984-1986 di pantai utara Jawa Tengah. Jurnal Penelitian Perikanan Laut, 40: 1--9.

Penn, J.W. 1984. The behaviour and catchability of some commercially exploited penaeids and their relationship to stock and recruitmen. In: J.A.Gulland \& B.J.Rothschild (Eds): Penaeid Shrimp-Their Biology and Management. Fishing News Book Ltd. Surrey. England. Hal:173--185.

Rijal,M \& B. Sumiono. 1989. Penelitian laju tangkap ikan demersal di perairan Kendal dan sekitarnya. Jurnal Penelitian Perikanan Laut, 53: 1--9.

Shindo, S. 1973. General review of the trawl fishery and the demersal fish stocks of the South China Sea. FAO. Fish. Tech. Pap. (120): 49 hal.

Sparre, P. \& S.C. Venema. 1992. Introduction to tropical fish stock assessment. Part 1. Manual. FAO Fish. Tech. Pap., (306/1) Rev. 1: 376 hal.

Suhendrata, T \& M. Badrudin. 1990. Sumber daya perikanan demersal di perairan pantai utara Rembang. Jurnal Penelitian Perikanan Laut, 54: $1--7$. 
